\title{
АПРОБАЦІЯ МЕТОДИКИ ВИМІРЮВАННЯ ВМІСТУ ЗАЛИШКОВИХ КІЛЬКОСТЕЙ ПЕСТИЦИДІВ У ПЛОДАХ ТОМАТІВ
}

\author{
Н. Ю. ТЕРЕЩЕНКО, кандидат хімічнИХ наук, \\ Національний медичний університет імені О.О. Богомольця \\ О. І. ХИЖАН, кандидат хімічних наук, доцент \\ л. О. КОВШУН, доктор технічних наук, професор \\ Національний університет біоресурсів та природокористування \\ України \\ E-mail: hrybova_n@i.ua \\ olenakhyzhan@gmail.com \\ https://orcid.org/0000-0002-2986-3251
}

Анотація. Встановлено величини, що характеризують придатність розробленої та апробованої методики виконання вимірювань вмісту залишкових кількостей пестицидів у плодах томатів. Встановлено, що робочий діапазон вимірювання залишкових кількостей пестицидів становить від 0,01 мг/кг до 1,0 мг/кг, похибка результатів випробування в рамках робочого діапазону не перевищує $10 \%$. Відсоток вилучення ксенобіотиків зі зразків встановлено в дослідженнях зразків плодів томатів, штучно збагачених пестицидами. Величина відсотку вилучення перебуває в діапазоні від 80\% до 110 \%, коефіцієнт варіації не перевищує 5 \%. Стабільність методики встановлена впродовж 6 місяців у серії внутрішньолабораторних досліджень редерентних зразків. Методика апробована в аналізі 53 зразків плодів томатів, 5 зразків томатної пасти та 10 зразків томатного соку. За результатами хроматографічного контролю на хроматограмах 47 зразків плодів томатів не було виявлено ксенобіотиків, виявлено один зразок плодів томатів та п'ять зразків томатної пасти зі слідовими кількостями цільових пестицидів (азоксистробін, дельтаметрин, диметоморф, металаксил-M, піраклостробін), вміст яких не перевищував встановлених нормативними документами в Україні та ЕС гігієнічних норм.

Ключові слова: плоди томатів, ксенобіотики, залишкові кількості пестицидів, апробація методики, хроматографія 


\section{Актуальність.}

В Україні районовано та вирощується понад 150 сортів і гібридів томатів, що відрізняються продуктивністю, строками дозрівання, типом, формою, забарвленням плодів та стійкістю проти різних хвороб. За вирощування цієї культури для мінімізації впливу руйнівних чинників та надання плодам томатів споживчих якостей, збереження корисних для організму людини властивостей використовують майже дві сотні препаратів засобів захисту рослин (33Р) (Коломієць Ю. В., Григорюк І. П., Буценко Л. М., 2015). Як правило, після застосування на культурі препаратів 33Р упродовж певного терміну в складі різних частин рослини акумулюються діючі речовини 3ЗР та здійснюють захист рослини від негативного фактору. Залишкові кількості пестицидів 33Р забезпечують захист рослини, водночас у цей період споживання плодів у їжу супроводжується потраплянням до організму споживача різної кількості небезпечних ксенобіотиків (Антоненко А. М., 2019). Для захисту здоров'я споживачів у розвинутих країнах світу вміст залишкових кількостей пестицидів у продукції рослинництва та продукції їхньої переробки нормується та ретельно контролюється. В Україні норми вмісту залишкових кількостей пестицидів встановлено державними санітарними правилами та нормами (ДСанПіН України 8.8.1.2.3.4000-2001). У ДСанПіН України 8.8.1.2.3.4-000-2001 також зазначено застосовану для здійснення відповідного лабораторного контролю методику виконання випробувань продукції (MBB). Також лабораторний контроль продукції рослинництва сьогодні здійснюється акредитованими лабораторіями різної форми власності згідно 3 апробованими, атестованими та зазначеними в сфері акредитації лабораторії МВВ. Належний лабораторний контроль продукції рослинництва на виробництві надає можливість виробникові виявляти та здійснювати контроль критичних точок виробництва, виготовляти безпечну та якісну продукцію. Слід зазначити, що експортні партії продукції, зазвичай, потребують від виробника контролю за значно ширшим, у порівнянні із встановленим ДСанПіН України 8.8.1.2.3.4000-2001, переліком залишкових кількостей пестицидів. Кожна країна-імпортер української продукції має власний перелік ксенобіотиків і здійснює відповідний лабораторний контроль на своїй території. Водночас в Україні є потреба виконання відповідних досліджень для забезпечення захисту національних виробників та забезпечення їх конкурентоспроможності на зовнішніх ринках.

\section{Аналіз останніх досліджень та публікацій.}

Оскільки державні стандартизовані методи лабораторного контролю не так швидко оновлюються, а державні вимоги до безпечності лише 3 часом гармонізуються відповідно до іноземних вимог, виробники-експортери проводять сертифікацію продукції у відповідних іноземних лабораторіях, або в акредитованих науково-дослідницьких підрозділах провідних наукових установ країни (Ушкалов В. О., Данчук В. В., Самкова О. П., Баранов Ю. С., Виговська Л. М., Войціцький В. М., Щербань $Є$. П., 2017). Дослідження переважної 
кількості найменувань залишкових кількостей ксенобіотиків, у тому числі пестицидів, проводять за допомогою хроматографічних методів із різними типами детекторів. Наприклад, автори роботи (Melo A., Cunha S. C., Mansilha C., Aguiar A., Pinho O., Ferreira I. M., 2012). застосували метод газової мас-спектрометрії (ГХ/MC) $\mathrm{MC)}$ до аналізу залишкових кількостей пестицидів у екстрактах зразків продукції рослинництва. Робочий діапазон вимірювання залишкових кількостей пестицидів у складі зразку становив від $0.01 \mathrm{мг} /$ кг до 0.2 мг/кг, мінімальний відсоток вилучення ксенобіотиків становить не менше $70 \%$, а максимальний не більше $116 \%$. Величина відносного стандартного відхилення середньої величини виміряної кількості вмісту пестициду залежить від його хімічної групи та будови молекули, варіюється в діапазоні від 3\% до 19\%, за винятком хлороталонілу (23\%). Отримані в роботі (Albero B., Sánchez-Brunete C., Tadeo J. L., 2003) дані говорять, що авторами роботи запропоновано задовільні умови вилучення і вимірювання пестицидів у складі рослинної витяжки. У роботі (Cortés J. M., Vázquez A., Santa-María G., Blanch G. P., Villén J. 2009) для кількісного визначення залишків пестицидів було запропоновано нову методику, що відрізнялась етапом очищення витяжки пестицидів від коекстрактивних сполук матриці за допомогою гель-проникної хроматографії. Застосування гель-проникної хроматографії дозволило отримати очищені від матричних сполук розчини пестицидів та встановити їхній уміст методом газової хроматографії (ГХ/MC) та методом рідинної хроматографії (BEPX/MC/MC). Встановлено, що межа виявлення пестицидів залежить від хімічної структури аналіту та перебуває в діапазоні від 0,2 мг/кг до 6,0 мг/кг, коефіцієнт кореляції лінійної залежності зони робочих концентрацій становив $r \geq 0.98$. Автори виконали валідаційні дослідження запропонованого аналітичного методу для визначення залишкових кількостей пестицидів у зеленій масі та зразках овочів та фруктів. Результати атестації методики показали, що відсоток вилучення пестицидів перебувають у діапазоні від 80 до 120 \%. Тим часом автори роботи, досліджуючи результати апробації запропонованої методології в трьох різних лабораторіях встановили, що для забезпечення $100 \%$ виявлення та ідентифікації цільових пестицидів необхідними $є$ узгодження в роботі застосованого вимірювального обладнання.

Метою досліджень є апробація методики лабораторного контролю вмісту залишкових кількостей пестицидів у плодах томатів, томатній пасті та томатному соку.

\section{Матеріали і методи досліджень.}

Робота проведена з використанням розчинників та реактивів кваліфікації «для хроматографії» та «ч.д.а.»: ацетонітрил, метанол, деіонізована вода, мурашина кислота, оцтова кислота, трифтороцтова кислота, хлоридна кислота, сульфатна кислота, гідроксид натрію, сульфат магнію, хлорид натрію, хлорид кальцію, цитрат натрію. Для очищення рослинних витяжок від коектсрактивних речовин використовували сорбенти: $\mathrm{Al}_{2} \mathrm{O}_{3}$ та $\mathrm{nSiO}_{2}$, активоване вугілля марки ОУ-А (ДСТУ 4453-74), колонки ТФЕ (ChromSpher $\left.\mathrm{Pi}, \operatorname{Varian}^{\mathrm{TM}}\right)$, картриджі, заповнені 
сумішами первинних і вторинних амінів виробництва Supelco, картриджи, заповнені вугіллям графітизованим виробництва Supelco. Відбір проб здійснено згідно $з$ відповідною нормативною документацією. У роботі застосовано зразки продукції рослинництва: плоди томатів різних сортів, томатну пасту та томатний сік. Сформовано паралельні лабораторни проби, з яких по три проби в рамках одного дослідження, були штучно збагачені цільовими ксенобіотиками або маркерами різних груп ксенобіотиків.

Гомогенізація проб проводилася шляхом подрібнення в стакані лабораторного млину-гомогенізатору Л3М-1, за різних температур (від $+4{ }^{\circ} \mathrm{C}$ до $\left.+25^{\circ} \mathrm{C}\right)$. Для буферизаціï розчину шару гомогенізованого зразка та на етапі очистки рослинної витяжки використовували хімічні сполуки кваліфікації «ч.д.а.»: сульфат магнію, хлорид натрію, цитрат натрію дигідрат, цитрат калію, хлорид кальцію, оксид алюмінію. Екстракція здійснювалася методом мацерації в пластикових пробірках iз політетрафторетилену, у колбах iз темного скла та пластикових колбах із поліметилпентену, захищених світлонепроникними кожухами. Інтенсифікація масоперенесення під час вилучення аналітів відбувалася за варіювання співвідношення сировина-екстрагент, під дією температури, перемішування, ультразвукових хвиль частотою 37 кГц (генерувалися установкою фірми Advantage Lab).

Розділення фаз екстракційної системи проведено із використанням центрифуги Thermo Scientific, протягом 10 хв. за сталого обертання зі швидкістю від 4000 до 7000 обертів за хвилину, за температури в камері центрифуги від $4{ }^{\circ} \mathrm{C}$ до $20^{\circ} \mathrm{C}$. Отримана рослинна витяжка виокремлена після центрифугування від рослинного матеріалу була очищена від коекстрактивних речовин методами дисперсійної твердофазної екстракції 3 використанням органічних розчинників та сорбентів: сумішей первинних і вторинних амінів, графітизованого вугілля або за допомогою рідинно-рідинної переекстракції. Концентрування очищеної витяжки ксенобіотиків проведено за допомогою ротаційного випаровувача фірми IКА. Аналіз умісту ксенобіотиків в отриманих із витяжок розчинів проведено відповідно до переліку аналітів методом високоефективної хроматографії 3 мас-селективним детектором із застосуванням хроматографу Dionex Summit MSD-3200Q TRAP, методом газової мас-спектрометрії із застосуванням хроматографу GC/MS A.01.10.3/Agilent Technologies, методом високоефективної рідинної хроматографіï із флуоресцентним та діодноматричним детекторами (BEPX/ ФЛД та ВЕРХ/ДАД/ФЛД) із застосуванням хроматографів Ultimate 3000 фірми Dionex. Результати аналітичних сигналів, спектри аналітів опрацьовано за допомогою калібрувальних залежностей, бібліотеки баз даних програми Cromeleon 6.0 та бібліотеки мас-спектрів NIST 0.5.

\section{Результати досліджень ма іх обговорення.}

Методика вимірювання вмісту залишкових кількостей пестицидів у зразках продукції рослинництва складається із трьох основних етапів: отримання рослинної витяжки, отримання робочих розчинів, здійснення інструментального контролю вмісту ксенобіотиків. 
На першому етапі з гомогенізованого зразка продукції рослинництва відбувається екстракція зі зразка наявних пестицидів до складу рослинної витяжки. Для цього створюється система органічний розчинник - водно-сольовий розчин - гомогенізований зразок. В органічний шар екстрагуються не тільки цільові пестициди, а й коекстрактивні речовини.

Як можна бачити 3 таблиці 1 до рослинної витяжки екстрагуються 22 хімічні сполуки, хімічний склад коекстрактивних речовин не досліджувався, оскільки коекстрактивні сполуки виокремлюються 3 рослинної витяжки за допомогою методів твердофазної та рідинно-рідинної екстракції (ТФЕ та PPE). Рослинна витяжка пестицидів досліджується хроматографічними методами згідно з умовами атестованої методики, розробленої для кількісного вимірювання певної групи аналітів у продукції рослинництва. Як можна бачити 3 таблиці 1 нижня межа визначення залишків пестицидів різних хі- мічних груп перебувають на рівні 0.01 мг/кг, похибка вимірювання не перевищує $10 \%$. Порівнюючи величину нижньої межі визначення аналіту та норми його вмісту у плодах томатів (ДСанПіН 8.8.1.2.3.4-000-2001, 2001) та продуктах їхньої переробки було встановлено, що дана методика дозволяє контролювати вище зазначені показники безпечності. Верхня межа визначення залишків пестицидів, наведених у таблиці 1 становить 1.0 мг/кг, похибка вимірювання не перевищує $4 \%$.

Для підтвердження можливості визначення вмісту пестициду в присутності інших ксенобіотиків цим методом, а також у випадку не повного очищення рослинної витяжки від коекстрактивних речовин, у роботі проведено аналіз рослинних витяжок, що не містили аналітів (3 паралелі холостих проб), модельних систем та штучно збагачених пестицидами зразків плодів томатів із різними варіаціями хімічного складу аналітів і коекстрактивних сполук.

\section{1. Перелік цільових пестицидів, нижня межа та похибка кількісного вимірювання аналіту $(\mathrm{N}=3, \mathrm{n}=10, \mathrm{P}=0,95)$}

\begin{tabular}{|c|c|c|c|c|c|}
\hline Сполука & $\begin{array}{c}\text { Нижня межа, } \\
\text { мг/кг }\end{array}$ & $\begin{array}{c}\text { Похибка, } \\
\text { \% }\end{array}$ & Сполука & $\begin{array}{c}\text { Нижня межа, } \\
\text { мг/кг }\end{array}$ & $\begin{array}{c}\text { Похибка, } \\
\text { \% }\end{array}$ \\
\hline азоксистробін & 0,01 & 9,8 & піраклостробін & 0,01 & 9,0 \\
\hline дельтаметрин & 0,01 & 9,5 & римсульфурон, & 0,01 & 10,0 \\
\hline диметоат & 0,01 & 9,1 & тіаметоксам & 0,01 & 10,0 \\
\hline диметоморф & 0,01 & 9,5 & тебуконазол & 0,01 & 9,3 \\
\hline дифеноконазол & 0,01 & 9,0 & тіаклоприд & 0,01 & 9,7 \\
\hline метоміл & 0,01 & 10,0 & тербутилазин & 0,01 & 9,1 \\
\hline манкоцеб & 0,01 & 9,6 & фамоксадон & 0,01 & 9,3 \\
\hline металаксил-м & 0,01 & 9,2 & флудиоксоніл & 0,01 & 9,7 \\
\hline $\begin{array}{l}\text { лямбда-цига- } \\
\text { лотрин }\end{array}$ & 0,01 & 9,6 & $\begin{array}{c}\text { флуазифоп-п-бу- } \\
\text { тил }\end{array}$ & 0,01 & 9,9 \\
\hline метрибузин & 0,01 & 10,0 & хілазофоп-п-етил & 0,01 & 9,8 \\
\hline s-метолахлор & 0,01 & 9,7 & хлорпірифос & 0,01 & 9,5 \\
\hline
\end{tabular}




\section{2. Діапазон внесеної кількості пестицидів та метрологічні характеристики встановленої величини вмісту}

\begin{tabular}{|c|c|c|c|c|c|}
\hline \multirow[t]{2}{*}{ Сполука } & \multirow{2}{*}{$\begin{array}{c}\text { Внесено, } \\
\text { мг/кг }\end{array}$} & \multicolumn{4}{|c|}{$\begin{array}{l}\text { Метрологічні характеристики } \\
\text { встановленої величини вмісту }\end{array}$} \\
\hline & & $\mathrm{XCP}$ & $\mathrm{CV}, \%$ & Вилучення, \% & Похибка, \% \\
\hline \multirow{3}{*}{ Азоксистробін } & 0,01 & 0,01 & 3,8 & $90-110$ & 10 \\
\hline & 0,05 & 0,04 & 2,7 & $80-100$ & 10 \\
\hline & 1,0 & 0,97 & 3,0 & $95-101$ & 3,1 \\
\hline \multirow{3}{*}{ Диметоморф } & 0,01 & 0,01 & 4,2 & $92-108$ & 8 \\
\hline & 0,05 & 0,05 & 3,1 & $90-110$ & 10 \\
\hline & 1,0 & 0,96 & 3,5 & $92-100$ & 4 \\
\hline \multirow{3}{*}{ Тебуконазол } & 0,01 & 0,01 & 4,0 & $90-100$ & 10 \\
\hline & 0,05 & 0,05 & 3,9 & $90-100$ & 10 \\
\hline & 1,0 & 0,90 & 4,6 & 84-98 & 6 \\
\hline \multirow{3}{*}{ Хлорпірифос } & 0,01 & 0,01 & 3,2 & $90-100$ & 10 \\
\hline & 0,05 & 0,05 & 3,9 & $90-100$ & 10 \\
\hline & 1,0 & 0,90 & 3,3 & $87-93$ & 6,5 \\
\hline
\end{tabular}

Як можна бачити 3 таблиці 2, отримані середні значення очікуваних величин (ХСР) збігаються у межах похибки із внесеними до зразка рівнями вмісту ксенобіотиків. Під час апробації досліджено та підтверджено, що робочий діапазон вимірювання залишкових кількостей пестицидів у складі зразка становить від $0.01 \mathrm{мг/кг} \mathrm{до} 1.0 \mathrm{мг} /$ кг, мінімальний відсоток вилучення ксенобіотиків становить не менше $80 \%$, а максимальний не більше $110 \%$, похибка вимірювання не перевищує $10 \%$ та зменшується в діапазоні концентрацій аналіту від 0.5 мг/кг до 1.0 мг/кг. Величина коефіцієнта варіації виміряної кількості вмісту пестициду варіюється в діапазоні від 2 \% до 5 \%. Наведені в таблиці 2 дані отримано за результатами хроматографічного аналізу. Виявлення піків аналітів нижньої межи кількісного вимірювання (0,01 мг/ кг) проведено при співвідношеннях шум/сигнал від 1 шум: 6 сигнал. Використані інструментальні методи мас-спектрометрії газової та рідинної хроматографії є селективними методами. Під час отримання хроматограм у методі рідинної хроматографії застосовано селективні умови збору іонів відповідного аналіту. У методі газової мас-спектрометрії під час обробки хроматограм застосовано функцію очищення спектрів, принцип мас-фрагментації - виділення із сукупності мас-йонів, отриманих за іонізації електронним ударом (70 еВ), мас-йонів характерних для цільового аналіту. У поєднанні 3 часом утримування, зафіксованим відповідно до часу утримання аналітичного стандарту, це полегшує опрацювання результатів хроматографічного аналізу.

Було проаналізовано 53 зразків плодів томатів, 5 зразків томатної пасти та 10 зразків томатного соку. За результатами хроматографічно- 


\section{3.Перелік пестицидів та результати контролю їх залишкових кількостей в зразку плодів томатів р.к. 12}

\begin{tabular}{|l|c|c|c|}
\hline \multicolumn{1}{|c|}{ Найменування показників } & Визначено, мг/кг & Норми * & Норми ** \\
\hline Азоксистробін & 0,01 & не нормується & 0,3 \\
\hline Дельтаметрин & 0,01 & 0,3 & 0,3 \\
\hline Диметоморф & $<0,01$ & не нормується & 0,1 \\
\hline Металаксил-М & 0,01 & 0,04 & 0,2 \\
\hline Піраклостробін & $<0,01$ & 0,3 & 0,3 \\
\hline
\end{tabular}

* Державні санітарні правила та норми ДСанПіН 8.8.1.2.3.4-000-2001

** PESTICIDES EU-MRLs Regulation (EC) No 396/2005, Tomatoes.

го контролю на хроматограмах 47 зразків не було виявлено (за часом утримання та мас-спектромами піків) ксенобіотиків, що відповідали сполукам пестицидного характеру. Переважна більшість зразків не містила пестицидів. Водночас у роботі виявлено один зразок плодів томатів та п'ять зразків томатної пасти iз вмістом цільових пестицидів. Результати встановленої кількості пестицидів у томатах та томатній пасті співставленні 3 їхнім допустимим умістом, дозволеним ДСанПіН України 8.8.1.2.3.4-000-2001. У томатній пасті виявлено від одного до чотирьох пестицидів у кількості, що не перевищувала встановлених гігієнічних нормативів. У томатах реєстраційний код (р.к.) 12 виявлено п'ять пестицидів, інших хімічних сполук пестицидного характеру не виявлено.

У кожному зі зразків томатної пасти та в зразку плодів томатів р.к. 12, наведеного в таблиці 3, виявлено диметоморф. Диметоморф - діюча речовина препаратів захисту рослин фунгіцидної дії, дозволений для захисту овочевих культур картоплі, томатів, огірків, цибулі та винограду від комплексу хвороб. Згідно 3 рекомендаціями із засто- сування обприскування рослини препаратом проводять до появи перших ознак хвороби й обробляють протягом всього періоду вегетації 3 інтервалом від 7 до 14 днів. Самостійно диметоморф не застосовується, цей пестицид входить до складу трьох-компонентних та двох-компонентних препаратів із манкоцебом, піраклостробіном, металаксилом або аметоктрадином. Манкоцеб у навколишньому середовищі нестабільний, швидко гідролізується (від декількох годин до трьох діб) у кислому та лужному середовищі, виявити залишкові кількості цієї сполуки в зразках можна лише в перші дні після обробки рослини. Залишкові кількості піраклостробіну та металаксилу-М виявлені в продукції, говорять про те, що ці пестициди не лише $є$ стійкими в навколишньому середовищі, а й не розкладаються в умовах пастеризації. Аналізуючи залишкові кількості діючих речовин виявлених препаратів можна припустити, що препарати застосовувалися згідно 3 інструкціями i не перевищували рекомендованих норм внесення. Виявлені залишкові кількості пестицидів є меншими за величини максимально допустимого рівня вмісту. 


\section{Висновки та перспективи досліджень.}

У роботі проведено апробацію методики вимірювання залишкових кількостей пестицидів, що залишаються в складі плодів томатів після застосування на культурі засобів захисту рослин. Встановлено, що робочий діапазон вимірювання залишкових кількостей пестицидів становить від 0.01 мг/кг до 1.0 мг/кг. Величина відсотку вилучення пестицидів зі зразка до рослинної витяжки пербуває в діапазоні від $80 \%$ до $110 \%$, величина коефіцієнта варіації не перевищує $5 \%$. Стабільність методики встановлена упродовж 6 місяців у серії внутрішньо лабораторних досліджень референтних зразків. Методика апробована із застосуванням модельних систем та 53 зразків плодів томатів, 5 зразків томатної пасти, 10 зразків томатного соку. Виявлено один зразок плодів томатів та п'ять зразків томатної пасти зі слідовими кількостями кількох цільових пестицидів, вміст яких не перевищував встановлених гігієнічних норм.

\section{References}

1. Kolomiiets, Yu. V., Hryhoriuk, I. P., , Butsenko, L.M. (2015), Efektyvnist vplyvu funhitsydiv na zbudnykiv bakterialnykh khvorob tomativ. Visnyk ahrarnoi nauky, 10, 21-24. http://agrovisnyk.com/pdf/ ua_2015_10_04.pdf

2. Antonenko A. M. (2019), Pestytsydy yak chynnyky ryzyku rozvytku khvorob shchytopodibnoi zalozy: hihiienichna rehlamentatsiia ta obgruntuvannia kryteriiv hihiienichnoho monitorynhu.: avtoref. dys. na zdobuttia nauk. stupenia d-ra med. nauk : spets. 14.02 .01 «Hihiiena ta profesiina patolohiia» / Antonenko Anna Mykolaivna;
Natsionalnyi med. un-t im. O.O. Bohomoltsia MOZ Ukrainy. - K., 2019. - 36 s.

3. Ushkalov, V. O., Danchuk, V. V., Samkova, O. P., Baranov, Yu. S., Vyhovska, L. M., Voitsitskyi, V. M., ... \& Shcherban, Ye. P. (2017). Biolohichna bezpeka: rezultaty monitorynhu ahroresursiv, produktsii APK ta kharchovykh produktiv za 2014-2016 roky. Veterynarna medytsyna: Mizhvidomchyi tematychnyi naukovyi zbirnyk, 103, 88-92. http://jvm.kharkov.ua/ sbornik/103/1_22.pdf

4. Melo, A., Cunha, S. C., Mansilha, C., Aguiar, A., Pinho, O., \& Ferreira, I. M. (2012). Monitoring pesticide residues in greenhouse tomato by combining acetonitrile-based extraction with dispersive liquid-liquid microextraction followed by gas-chromatography-mass spectrometry. Food chemistry, 135(3), 1071-1077. doi: 10.1016/j.foodchem.2012.05.112.

5. Albero, B., Sánchez-Brunete, C., \& Tadeo, J. L. (2003). Determination of endosulfan isomers and endosulfan sulfate in tomato juice by matrix solid-phase dispersion and gas chromatography. Journal of chromatography $A, 1007(1-2), 137-143$. https://www. sciencedirect.com/journal/journal-of-chromatography-a/vol/1007/issue/1 doi: 10.1016/S0021-9673(03)00954-3

6. Cortés, J. M., Vázquez, A., Santa-María, G., Blanch, G. P., \& Villén, J. (2009). Pesticide residue analysis by RPLC-GC in lycopene and other carotenoids obtained from tomatoes by supercritical fluid extraction. Food chemistry, 113(1), 280-284. https://www. sciencedirect.com/journal/food-chemistry/vol/113/issue/1 doi : 10.1016/j.foodchem.2008.07.010

7. DSanPYN 8.8.1.2.3.4-000-2001. Dopustymi dozy, kontsentratsii, kilkosti ta rivni vmistu pestytsydiv u silskohospodarskii syrovyni, kharchovykh produktakh, povitri robochoi zony, atmosfernomu povitri, vodi vodoimyshch, hrunti. Postanova Holovnoho derzhavnoho sanitarnoho likaria Ukrainy vid 20.09.2001 № 137. 
Tereshchenko N., Khyzhan O., Kovshun L. (2020). APPROBATION OF METHOD MEASURING A PESTICIDES RESIDUAL CONTENT IN TOMATOES.

PLANT AND SOIL SCIENCE, 11(1): 88-96. https://doi.org/10.31548/agr2020.01.088

Abstract. Approbation of method was studied, the values which characterizing the suitability of the developed and tested method measuring a pesticides residual content in tomatoes have been established. It is established that the working range of measurement of pesticide residues is from $0.01 \mathrm{mg} / \mathrm{kg}$ to $1.0 \mathrm{mg} / \mathrm{kg}$, the error of the test results within the working range does not exceed $10 \%$. Percentage of xenobiotics extracted from samples was established in studies of tomatoes samples artificially enriched with pesticides. The percentage of extraction is in the range of $80 \%$ to $110 \%$, the coefficient of variation does not exceed $5 \%$. The stability of the technique is established for 6 months in a series of in-laboratory studies of reference samples. The technique was tested in the analysis of 53 samples of tomato fruits, 5 samples of tomato paste and 10 samples of tomato juice. According to the results of chromatographic control by chromatograms of 47 tomato fruits samples, no xenobiotics were detected, one sample of tomatoes and five samples of tomato paste with trace amounts of target pesticides were detected (azoxystrobin, deltamethrin, dimethomorph, metalaxyl-M, pyraclostrobin) according to the Ukraine and the EU hygiene standards.

Keywords: tomatoes, xenobiotics, pesticide residues, method approbation, chromatography 